\title{
Development of habitat suitability criteria for Neotropical stream fishes and an assessment of their transferability to streams with different conservation status
}

\author{
Fabrício Barreto Teresa ${ }^{1}$ and Lilian Casatti ${ }^{2}$
}

\begin{abstract}
We assessed the preference of 10 fish species for depth and velocity conditions in forested streams from southeastern Brazil using habitat suitability criteria (HSC curves). We also tested whether preference patterns observed in forested streams can be transferred to deforested streams. We used data from fish sampled in 62 five-meter sites in three forested streams to construct preference curves. Astyanax altiparanae, A. fasciatus, Knodus moenkhausii, and Piabina argentea showed a preference for deep slow habitats, whereas Aspidoras fuscoguttatus, Characidium zebra, Cetopsorhamdia iheringi, Pseudopimelodus pulcher, and Hypostomus nigromaculatus showed an opposite pattern: preference for shallow fast habitats. Hypostomus ancistroides showed a multimodal pattern of preference for depth and velocity. To evaluate whether patterns observed in forested streams may be transferred to deforested streams, we sampled 64 five-meters sites in three deforested streams using the same methodology. The preference for velocity was more consistent than for depth, as success in the transferability criterion was $86 \%$ and $29 \%$ of species, respectively. This indicates that velocity is a good predictor of species abundance in streams, regardless of their condition.
\end{abstract}

Neste estudo avaliamos a preferência de 10 espécies de peixes por condições de profundidade e fluxo em riachos florestados do sudeste do Brasil por meio do critério de adequabilidade de habitat (habitat suitability criteria - curvas HSC). Testamos também se os padrões de preferência observados nos riachos florestados podem ser transferidos para riachos desmatados. Foram realizadas amostragens da ictiofauna em 62 trechos de cinco metros de extensão em três riachos florestados para a construção das curvas de preferência. Astyanax altiparanae, A. fasciatus, Knodus moenkhausii e Piabina argentea apresentaram preferência por habitats lentos e profundos, enquanto Aspidoras fuscoguttatus, Characidium zebra, Cetopsorhamdia iheringi, Pseudopimelodus pulcher e Hypostomus nigromaculatus apresentaram um padrão oposto de preferência por habitats rasos e de fluxo rápido. Hypostomus ancistroides apresentou um padrão de preferência por profundidade e fluxo multimodal. Para avaliar se os padrões observados nos riachos florestados podem ser transferidos para riachos desmatados foram realizadas amostragens da ictiofauna em 64 trechos de cinco metros de extensão em três riachos desmatados utilizando a mesma metodologia aplicada aos riachos florestados. O sucesso na transferência do critério foi de $86 \%$ e $29 \%$ para fluxo e profundidade, ou seja, a preferência por fluxo foi mais consistente do que por profundidade. Isso indica que o fluxo é um bom preditor da abundância das espécies em riachos, independentemente do seu estado de conservação.

Key words: Depth, Fish assemblages, Habitat preference, Riparian forest, Velocity.

\section{Introduction}

The recognition that species are distributed non-randomly in habitats, preferentially occupying suitable sites for feeding, reproduction, and survival (Grinnell, 1917; Hutchinson, 1957), constitutes the basis for developing predictive models of species distribution along environmental gradients (e.g., Ahmadi-Nedushan et al., 2006). This approach has a broad application for natural resources management, since it allows prediction of changes in biological communities from changes in environmental conditions caused by human activities. However, the predictive power of these models depends on knowledge of the response of species in relation to the gradient of environmental conditions. This information can be obtained by developing habitat suitability criteria (HSC) (Bovee, 1982, 1986), a component for conducting physical habitat simulation

${ }^{1}$ Universidade Estadual de Goiás - UEG, Unidade Universitária de Porangatu, Avenida Brasília, 32, 76550-000 Porangatu, GO, Brazil. fabricioteresa@yahoo.com.br

${ }^{2}$ Universidade Estadual Paulista - UNESP, Laboratório de Ictiologia, Departamento de Zoologia e Botânica, IBILCE, Rua Cristóvão Colombo, 2265, 15054-000 São José do Rio Preto, SP, Brazil. licasatti@gmail.com 
(PHABSIM), a tool used to assess the consequences of changes in river flows on habitat availability (Bovee, 1982).

The HSC can be assessed by curves defining the degree of preference by a given species in relation to habitat variables alone, such as depth, velocity, substrate, and cover. Efforts to develop HSC for multiple species have increased, owing to the degradation of water resources and growing concern over biodiversity loss (e.g., Lamouroux et al., 1999; Vadas \& Orth, 2001; Strakosh et al., 2003). However, this approach has not been applied in Neotropical environments, limiting the use of predictive models and the ability to quantitatively predict the biological impacts from changes in hydraulic variables of aquatic environments. This is especially alarming because changes in the natural flow regime are among the major anthropogenic threats for fish conservation in Neotropical lotic environments (Barletta et al., 2010).

Several factors, such as environmental heterogeneity, food availability, predation, competition, and habitat availability influence the patterns of species occupancy in riverine patches (Power, 1984; Thomas \& Bovee, 1993; Jackson et al., 2001; Leal et al., 2011). The differential effects of these factors may limit the applicability of HSC in environments or conditions other than that for which it was developed (Groshens \& Orth, 1993; Freeman et al., 1997; Vadas \& Orth, 2001). In these cases, the development of specific criteria for each type of stream or condition is recommended (Bovee, 1986), which brings high costs and operational difficulties. However, other studies have found consistency in preference patterns across streams (Thomas \& Bovee, 1993; Strakosh et al., 2003). This highlights the importance to validate HSC to the site of interest (transferability) before developing new criteria.

Our present goal was to evaluate the preference of different fish species for depth and velocity conditions in forested streams from southeastern Brazil, based on the development of HSC curves. Here, we also evaluated the consistency of habitat preference patterns of species in forested streams and test HSC transferability to deforested streams. In our study region, the clearing of native vegetation was a consequence of economic and social processes that occurred in the past, affecting about $75 \%$ of the riparian zones (Silva et al., 2007), and most streams have some degradation of their physical integrity that is directly or indirectly related to deforestation (Casatti et al., 2006). We focused on depth and velocity because they represent important predictors of fish community structure in streams (Lamouroux et al., 1999; Bürhnheim, 2002). Moreover, both forested and deforested streams had similar conditions considering these two variables, an important condition for the test of transferability (Freeman et al., 1997).

\section{Material and Methods}

\section{Study area}

All streams studied (second and third order) are located in the drainage of the São José dos Dourados River, upper
Paraná River basin, northwestern region of the state of São Paulo, Brazil (Fig. 1). The climate of the region is influenced by equatorial and tropical masses, resulting in a tropical climate with dry and rainy periods, with higher rainfall and higher temperatures from December to February and lower rainfall and milder temperatures between June and August (IPT, 1999). The forested streams are located within the greatest forest fragment (Seasonal Semideciduous Forest $>1.600 \mathrm{ha}$ ) of the basin and represent what is best preserved in the region (Fig. 1). The deforested streams are located in areas dominated by pasture, completely lacking arboreal vegetation in their riparian zone, presenting grass (Brachiaria spp.) proliferation on the banks (Fig. 1), with no evidence of chemical pollution. There are no representative forest remnants associated with deforested streams upstream or downstream of the study stretches. Both forested and deforested streams had similar conditions considering depth and velocity. Sites presented variation of 10.4 to $70.5 \mathrm{~cm}$ for depth and of 0.02 to $1.41 \mathrm{~m} / \mathrm{s}$ for velocity. The width was also variable (1.65 to $4.62 \mathrm{~m}$ ) such that depth and velocity was not perfectly correlated, although significant correlations between these variables has been verified in both forested and deforested streams (Pearson's product-moment correlation, $\mathrm{r}=0.57, \mathrm{p}<0.01 ; \mathrm{r}=0.29, \mathrm{p}<$ 0.01 , respectively).

\section{Fish sampling and environmental variables}

We collectively sampled 62 five-meter sites in three forested streams to identify the preference of fish species for depth and velocity and thus define habitat suitability criteria. In each stream we selected between 19 and 24 sites in order to represent the structural variation present in

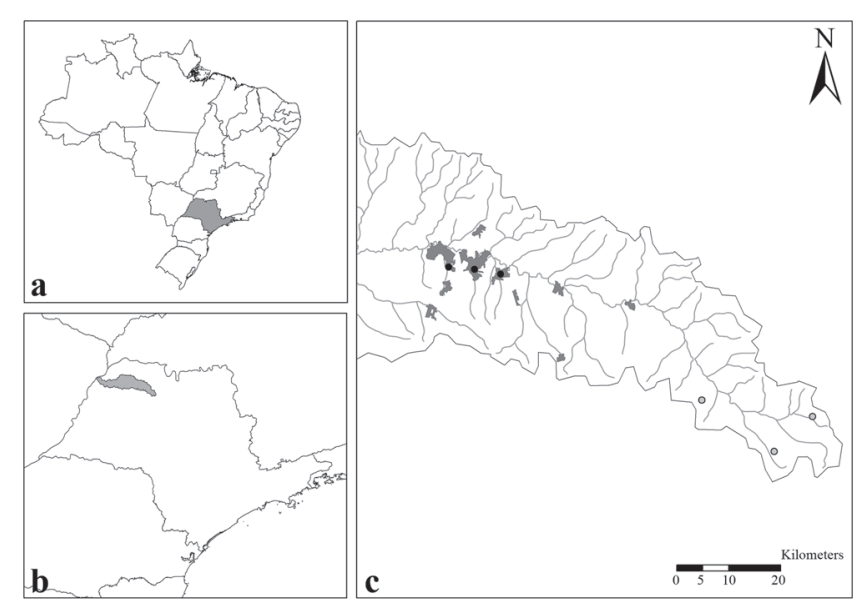

Fig. 1. Location of the study sites in the São José dos Dourados River basin, São Paulo State, Brazil (a and b). Forested sites (dark circles) are located within the greatest forest fragments and deforested (gray circles) streams lack arboreal vegetation in their riparian zone and are located in areas dominated by pasture (c). 
each stream. The fish samplings were carried out during the dry season (September to November 2009 and April to July 2010). The collection of fish was performed using electric fishing (stationary generator, AC, $220 \mathrm{~V}, 50-60 \mathrm{~Hz}$, 3.4-4.1 A, $1000 \mathrm{~W}$, as detailed by Castro et al., 2003) and consisted of successive passes from shore to shore along the site's lenght, until no individual was captured after a complete passage. Fish caught were fixed in a $10 \%$ formalin solution and after 48 hours transferred to a $70 \%$ ethanol solution. Voucher specimens of all species were deposited at the fish collection of the Departamento de Zoologia e Botânica da Universidade Estadual Paulista "Júlio de Mesquita Filho" (DZSJRP), São José do Rio Preto, São Paulo, Brazil (Table 1).

Each site was isolated upstream and downstream with block nets before sampling to prevent fish emigration or immigration while electric fishing sampling. The distance among sites in each stream was variable ( 3 to 300 meters). To verify if the distance among sites influenced the biological patterns observed within each stream, the relation between site distance and fish composition, represented by the similarity matrix based on Jaccard coefficient, was tested by a Relate routine (test for seriation). This analysis was used to test if changes in community composition exactly match the spatial sequence of sites (for example, community composition of first site on the longitudinal gradient is more similar to second site and less similar to third site, and so on with more distant sites being the most dissimilar). Additionally, significance was evaluated by permutation testing (Clarke \& Warwick, 2001). This analysis was not statistically significant ( $p>$ 0.07 ), revealing that the distance among sampled sites did not influence the results.

After fish sampling, we characterized the site in relation to depth and velocity. We divided each site into four equidistant, transverse transects, where depth measurements were obtained at five equidistant points from one margin to another. We used a mechanical flowmeter model 2030 (General Oceanics ${ }^{\circledR}$ ) to measure water velocity at $\sim 0.6$ times the total depth at the center of each transect. The values of depth and velocity for the whole site were obtained by calculating the mean values in each transect (depth) and across transects (velocity and depth).

\section{Development of habitat suitability criteria and test for transferability}

Only species that occurred in at least 10 samples in forested streams were included in the habitat suitability criteria for depth and velocity. We adopted this procedure because infrequent species may have been under-sampled, resulting in higher estimated errors of preference. We classified the depth gradient into five classes (D1 $=0$ to 0.2 $\mathrm{m} ; \mathrm{D} 2=0.21$ to $0.30 \mathrm{~m} ; \mathrm{D} 3=0.31$ to $0.40 \mathrm{~m} ; \mathrm{D} 4=0.41$ to 0.50 $\mathrm{m}$; D5 $>0.51 \mathrm{~m}$ ) and velocity into four classes (V1 $=0$ to 0.20 $\mathrm{m} / \mathrm{s} ; \mathrm{V} 2=0.21$ to $0.40 \mathrm{~m} / \mathrm{s} ; \mathrm{V} 3=0.41$ to $0.60 \mathrm{~m} / \mathrm{s} ; \mathrm{V} 4>0.61 \mathrm{~m} /$ $\mathrm{s})$. The limits for the classes were defined to represent discrete units of the hydrological gradient while ensuring a comparable number of samples in each class. We built HSC curves (type III, sensu Bovee, 1986) from preference values for each class of depth and velocity that were calculated as proportional abundance of species in each class of depth and velocity relative to total abundance, divided by the proportional number of sites in the class in relation to all sites sampled (1) (Freeman et al., 1997). With this procedure, we considered both the relative abundance of species in the habitats and habitat availability. Next, we standardized the preference values to vary from 0 to 1 , thereby obtaining the suitability index (SI). For the class with the highest preference value, we assigned an index of 1 and proportionally smaller values to other classes (2):

$$
\text { (1) } P_{i}=\frac{N_{i}}{H_{i}}{ }_{(2)} S I_{i}=\frac{P_{i}}{P_{\max }}
$$

where (1) $P_{\mathrm{i}}$ is the preference value for the class $i, N i$ is the proportional abundance of the species in the sites of class $i$ in relation to specimens sampled considering all sites and $H_{\mathrm{i}}$ is the proportional number of sites of the class $i$ in relation to all sites sampled; (2) $S I_{\mathrm{i}}$ is the suitability index for the class $i$ and $P_{\max }$ is the highest preference value obtained for a class.

We tested if the HSC developed for forested streams could be transferred to deforested streams. To do this, we sampled fish and environmental descriptors in 64 five-meter sites in three deforested streams (between 16 and 24 sites in each stream) during the same period and using the same methodology applied to forested streams. To test the transferability of HSC from forested to deforested streams, we considered only species that occurred in at least 10 sites in the deforested streams. We classified the deforested sites in optimum or nonoptimum according to the threshold defined from the HSC curves from forested streams. We considered optimal those deforested sites whose depth and velocity values fell into the classes that presented SI values greater than 0.7 in the forested streams. We choose 0.7 as a reference value because it included most of the raw values of habitat preference higher than 1.0 , i.e., whose relative abundance is higher than the proportional availability of habitats. In fact, $97.8 \%$ of depth and velocity classes with suitability index greater than 0.7 had preference scores of 1.0 or higher (scores combined across all species and sites). Conversely, only $5.5 \%$ of depth and velocity intervals with preference scores higher than 1.0 had SIs lower than 0.7. The definition of a threshold that defines optimal versus non-optimal sites goals to distinguish those habitat conditions with the greatest probability of sustaining populations of the target species (Freeman et al., 1997). For the criterion to be considered transferable, the abundance of a species should be higher in "optimal" than in "non-optimal" sites of deforested streams. Thus, we conducted a comparison of the mean 
species abundance between optimum and non-optimum sites of deforested streams using a one-tailed t-test ( 0.05 of significance level).

\section{Results}

We recorded 31 species in forested streams, of which 10 occurred in at least 10 samples (Table 1). The evaluation of the HSC curves for these species for depth and velocity demonstrated three main patterns (Fig. 2). Astyanax altiparanae, A. fasciatus, Knodus moenkhausii, and Piabina argentea had high SI values in slow-flowing and deep sites. Another four species showed an opposite pattern, with higher SI values associated with shallow and fast-flowing habitats. This was the case of Characidium zebra, Cetopsorhamdia iheringi, Pseudopimelodus pulcher, and Hypostomus nigromaculatus. Aspidoras fuscoguttatus and Hypostomus ancistroides showed distinct patterns from the above species and had the highest SI values in multiple classes of depth and in habitats with high and low water velocity, respectively (Fig. 2).

Only seven species to which we built HSC curves for forested streams also occurred in deforested streams (Table 2). In relation to depth, the mean abundance of $A$. altiparanae and $A$. fuscoguttatus was higher in optimal habitats of deforested streams, considering the threshold established in forested streams ( $\mathrm{t}$ test, $P<0.01$; Table 2). The abundance of the other species did not differ between optimal and nonoptimal habitats in deforested streams (t test, $P>0.15$; Table $2)$. In relation to water velocity, all species, except $H$. ancistroides, had higher abundances in optimal habitats of deforested streams, according to the criteria established for forested streams ( $\mathrm{t}$ test, $P<0.02$; Table 2).

\section{Discussion}

In this study we established the preference of ten species of stream fishes for depth and velocity conditions. In general, species showed well-defined preference patterns for depth and velocity, reinforcing the importance of hydraulic variables as predictors of fish distribution in lotic environments (Lamouroux et al., 1999; Vadas \& Orth, 2001; Schwartz \&
Herricks, 2008; Leal et al., 2011). One of the patterns was the association of $A$. altiparanae, A. fasciatus, K. moenkhausii, and $P$. argentea in deep, slow-flowing habitats. Indeed, the morphology of these species is compatible with this habitat preference, as their compressed bodies, well-developed anal fins, short caudal peduncle, lateral eyes represent morphological adaptations to live in lentic and slow-flowing waters (Gatz, 1979; Oliveira et al., 2010). Behavioral patterns displayed by these species also favor the occupation of lentic and deep habitats, as they are mid-water swimmers that feed on drift items in the water column (Casatti \& Castro, 1998; Casatti et al., 2001; Ceneviva-Bastos et al., 2010). Probably they are also favored in deep habitats with a higher habitat volume (i.e., water column) and where slow velocity requires less energy expenditure for movement and feeding (Casatti \& Castro, 1998; Bürhnheim, 2002).

An opposite pattern was observed for C. zebra, C. iheringi, $P$. pulcher, and $H$. nigromaculatus that showed preference for shallow and fast-flowing habitats. These fish have morphological and behavioral adaptations congruent with life in these conditions. For example, these species share depressed bodies and expanded pectoral fins (Casatti et al. 2005; Casatti \& Castro, 2006), which allow short movements in fast-flowing environments (Watson \& Balon, 1984). In addition, the diet composed of periphyton ( $H$. nigromaculatus) and aquatic insects (remaining species) is consistent with the high availability of these items in shallow, fast-flowing environments (Angermeier \& Karr, 1983).

The habitat suitability criteria obtained for $H$. ancistroides and A. fuscoguttatus were distinct from other species with respect to depth. Normally, a species response to environment is expected to be either monotonic or unimodal (Thomas \& Bovee, 1993; Vadas \& Orth, 2001; Strakosh et al., 2003), although different patterns can also be observed (Freeman et al., 1997). The bimodal pattern observed for A. fuscoguttatus might be an artifact of small sample sizes. Because this species occurred only in two forested streams, we did not consider the samples from the stream in which it was absent to calculate the habitat availability. Consequently, only five samples fell into the deepest depth class. Because the calculation of SI involves the relative abundance ratio of the proportional

Table 1. Voucher number, number of sites at which the species was recorded and number of individuals (in parentheses) of species occurring in at least 10 sites in forested streams (F1 to F3).

\begin{tabular}{llccccc}
\hline Family & \multicolumn{1}{c}{ Species } & Code & $\begin{array}{c}\text { Voucher number } \\
\text { (DZSJRP) }\end{array}$ & F1 & F2 & F3 \\
\hline Characidae & Astyanax altiparanae & Astalt & 8282 & $15(97)$ & $9(26)$ & $8(30)$ \\
& Astyanax fasciatus & Astfas & 6032 & $6(20)$ & $14(36)$ & $17(192)$ \\
& Knodus moenkhausii & Knomoe & 6079 & $8(17)$ & $10(30)$ & $8(13)$ \\
& Piabina argentea & Piaarg & 8055 & $13(35)$ & $11(34)$ & $12(42)$ \\
Crenuchidae & Characidium zebra & Chazeb & 6034 & $16(31)$ & $20(66)$ & $19(89)$ \\
Callichthyidae & Aspidoras fuscoguttatus & Aspfus & 8169 & $0(0)$ & $6(11)$ & $10(23)$ \\
Heptapteridae & Cetopsorhamdia iheringi & Cetihe & 5995 & $5(8)$ & $4(9)$ & $6(25)$ \\
& Pseudopimelodus pulcher & Psepul & 6173 & $11(42)$ & $9(38)$ & $0(0)$ \\
Loricariidae & Hypostomus ancistroides & Hypanc & 6036 & $6(10)$ & $10(23)$ & $16(38)$ \\
& Hypostomus nigromaculatus & Hypnig & 8280 & $18(69)$ & $14(47)$ & $11(87)$ \\
\hline
\end{tabular}



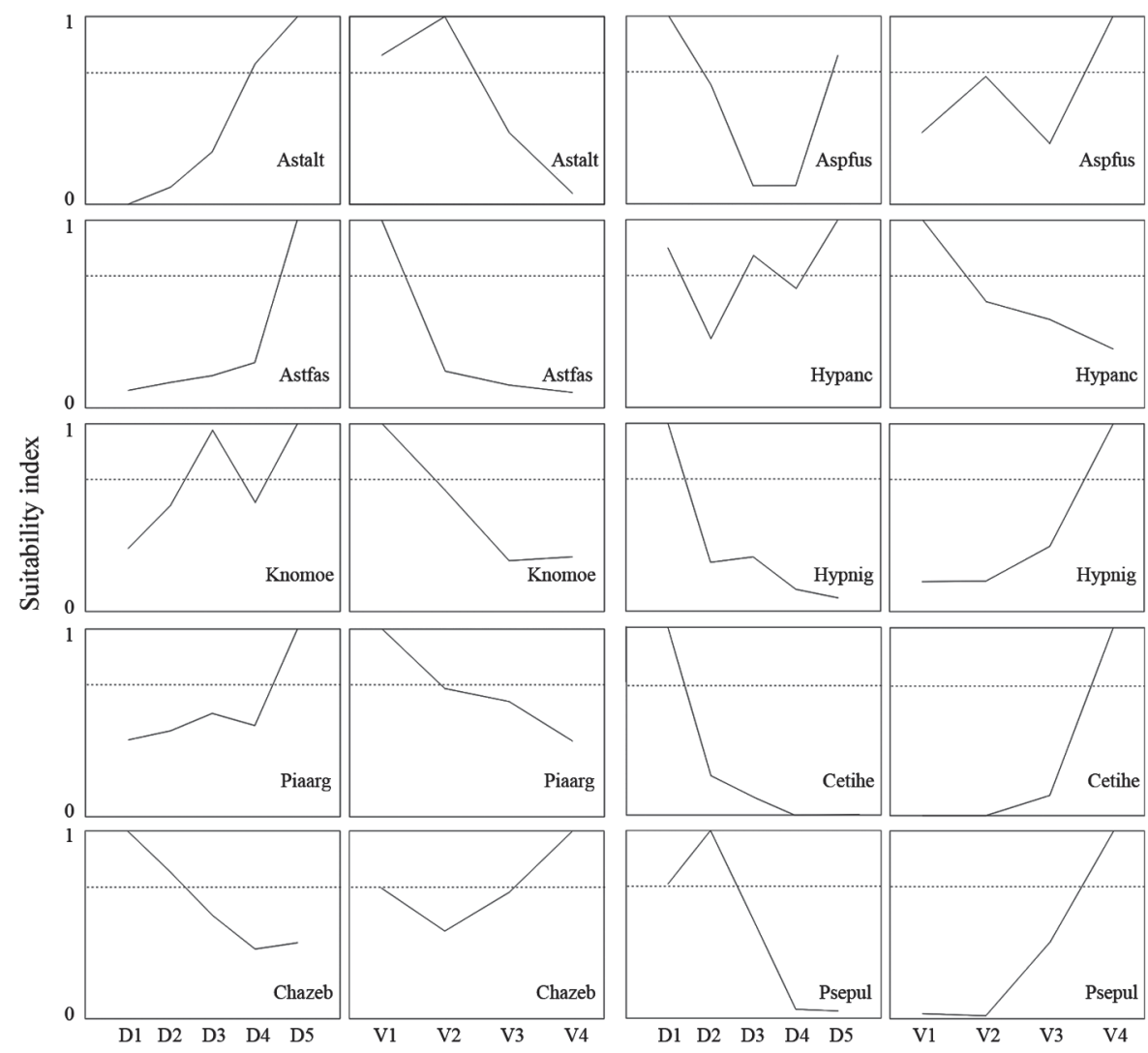

Fig. 2. Habitat suitability criteria for depth and velocity of 10 species (codes in Table 1) developed for forested streams, considering five classes of depth ( $\mathrm{D} 1=0$ to $0.2 \mathrm{~m} ; \mathrm{D} 2=0.21$ to $0.30 \mathrm{~m} ; \mathrm{D} 3=0.31$ to $0.40 \mathrm{~m}$; $\mathrm{D} 4=0.41$ to $0.50 \mathrm{~m} ; \mathrm{D} 5 \geq 0.51 \mathrm{~m}$ ) and four classes of velocity $(\mathrm{V} 1=>0.0$ to $0.2 \mathrm{~m} / \mathrm{s} ; \mathrm{V} 2=0.21$ to $0.40 \mathrm{~m} / \mathrm{s} ; \mathrm{V} 3=0.41$ to $0.60 \mathrm{~m} / \mathrm{s} ; \mathrm{V} 4 \geq 0.61 \mathrm{~m} / \mathrm{s}$ ). The dotted lines indicate $\mathrm{SI}=0.7$, above which conditions were considered optimal.

availability of habitat, the occurrence of a few individuals (seven) in two samples resulted in high SI values. One of the procedures that can be adopted in this case is either group together two adjacent classes to increase sample size or not take into account the SI value obtained (see Freeman et al., 1997). With the adoption of these procedures, the preference pattern of A. fuscoguttatus would be similar to species with a preference for shallow habitats, and therefore consistent with the pattern of habitat use reported for this species (Araujo \& Garutti, 2003). Although the criterion developed here is consistent in deforested streams, this was due to the preference of this fish for shallowest depth class, as no individual was recorded in the deepest depth class. This strengthens our suggestion that the second peak of the HSC curve for this species has no biological basis. The habitat use criterion for velocity indicated a preference for fastflowing habitats, but similar to C. zebra, other velocity conditions were considered habitable (SI values $>0.32$ ). This is consistent with the plasticity of this species, which occurs in streams with different hydrological characteristics (Casatti et al., 2009a,b).
The multimodal pattern observed in the depth preference curve of $H$. ancistroides suggests that this factor has little influence in determining its abundance patterns. On the other hand, velocity seems to be a good predictor of its abundance in forested streams, via a more uniform relationship, indicating a preference for lentic habitats, as also found by Uieda et al. (1997) and Casatti et al. (2005). Interestingly, this pattern is uncommon for species of Hypostomus, which are usually associated with fast-flowing habitats, like $H$. nigromaculatus in this study.

The conditions considered non-optimal in this study (SI $<0.7)$ are not necessarily uninhabitable. Within this range, one could still discriminate between a range of habitable or marginal conditions and another as uninhabitable (Thomas $\&$ Bovee, 1993), which would represent the conditions in which a given species would avoid to live. Most species that preferred shallow, fast-flowing habitats were less plastic, since there are a wider range of conditions that may be considered uninhabitable to them (SI values close to zero in two classes of depth and velocity), compared with species that preferred deep, slow-flowing habitats. The only 
Table 2. Transferability test of HSC from forested to deforested streams. The + sign indicates that the HSC developed for forested streams was able to predict the abundance of a given species in deforested streams, and the - sign indicates the opposite.

\begin{tabular}{lcc}
\hline \multirow{2}{*}{ Species } & \multicolumn{2}{c}{ Abundance } \\
\cline { 2 - 3 } & Depth & Velocity \\
\hline Astyanax altiparanae & + & + \\
Astyanax fasciatus & - & + \\
Piabina argentea & - & + \\
Characidium zebra & - & + \\
Aspidoras fuscoguttatus & + & + \\
Hypostomus ancistroides & - & - \\
Hypostomus nigromaculatus & - & + \\
\hline
\end{tabular}

exception to this pattern was C. zebra, whose non-optimal, but occupied conditions could be considered habitable, as the SI values were higher than 0.37 . Species that preferred deep, slow-flowing habitats showed SI values close to zero in a maximum of one class of depth and velocity. This indicates that species that preferred shallow, fast-flowing habitats are more specialized and probably more sensitive to changes in hydraulic conditions. In fact, the loss of rheophilic species in streams from our study region has been attributed to changes in hydraulic conditions and simplification of habitats (Casatti et al., 2006; Casatti et al., 2009a; Teresa \& Casatti, 2010). For example, C. iheringi and $P$. pulcher did not occur in the degraded streams studied by Casatti et al. (2009a), a fact that they attributed to the loss of riffles from siltation and habitat simplification.

The analysis of HSC transferability from forested to deforested streams revealed that the preference of fish species is partially consistent across environments of different conservation status. Depth HSCs could be transferred to only two out of seven species (29\%), whereas velocity HSCs could be transferred to six out of seven species $(86 \%)$. These results indicate that the need to develop specific criteria for each condition depend on the variable considered, with velocity having higher transferability than depth. The failure to transfer HSCs may be due to different factors, such as (i) the preferred conditions are not available, (ii) interaction with other factors in deforested streams and (iii) failure of the criterion to describe optimal habitats. The first explanation may, at least partially, justify the failure in transferring the criteria for depth, especially for species whose optimum condition was assigned to the last depth class $(>0.51 \mathrm{~m})$ like $A$. fasciatus. In deforested streams, only four sites $(\sim 6 \%)$, three of which in the same stream, fell into the deepest depth class. According to Bovee (1986), the successful transfer of HSC is dependent on the availability of conditions in the site to which one wants to transfer the criterion.
The second explanation (interaction with other factors) may also apply if environmental factors influenced fish differently in forested as opposed to deforested streams. For example, the high abundance of marginal submerged vegetation in deforested streams, as a result of the proliferation of exotic grasses, provide favorable microhabitats for some species (Casatti et al., 2009a) and may influence their response to other variables. Such grasses can attenuate water flow along stream banks, providing slow-flowing microhabitats even in sites with high velocities. As a result, species with preferences for slow-flowing habitats would be favored, notably $H$. ancistroides in our study. In fact, individuals of this species were observed in the vegetation on the banks of deforested streams, even in sites with high water flow. On the other hand, this species was restricted to the mid-channel in forested streams, where submerged grasses are lacking and supposedly the influence of velocity is higher. This could explain the failure to transfer the criterion for flow velocity to H. ancistroides.

The failure in transferring HSCs also may be related to the fact that they do not always describe a habitat preferred by species. For example, in this study, depth and velocity covaried in both forested and deforested streams, so that the preference patterns observed for a variable (e.g., depth) can be influenced by a second variable (velocity). If the pattern for depth preference of species is an artifact of their association with velocity, then one would expect a distinct preference pattern for this variable (i.e., failure to transfer HSCs) only if the velocity-depth relationship was different between forested and deforested streams. In fact this happened, as a higher proportion of sites classified into the fourth velocity class $(>0.6 \mathrm{~m} / \mathrm{s})$ were grouped into classes with higher depth (D2, D3, and D4) in the deforested streams. This could explain the failure to transfer depth HSCs among streams for species that showed preference for fast-flowing habitats, like H. nigromaculatus and C. zebra.

The results indicated a high consistency in the response of species for velocity, suggesting that this variable is a good predictor of species abundance and that its HSC has great potential to be transferred to streams of different conservation status. Despite the criteria developed and tested in this study were based on samples collected over a dry season, it is expected that the same patterns emerge in wet season. This expectation is based on the weak effect of seasonality on the fish composition and assemblage structure in the studied region (Ferreira \& Casatti, 2006; Rocha et al., 2009). The successful transference of criteria in a landscape scale as shown in this study is relevant, mainly considering that transferability of criteria is usually tested between streams (Thomas \& Bovee, 1993) or between regional models built for individual streams (Lamouroux et al., 1999). The data presented in this study should represent part of an effort to develop criteria for Neotropical species, encompassing a broader spectrum of conditions, as well as other variables known to be important for fish, like substrate and cover (Vadas \& Orth, 2001; Wright \& Flecker, 2004; Leal et al., 2011). 


\section{Acknowledgments}

We are grateful to many people in the São Paulo State University who helped during data collection; to Gabriel L. Brejão for figure 1; to Fábio Cop Ferreira (São Paulo State University), Robert L. Vadas Jr (Washington Department of Fish \& Wildlife), Fernando M. Pelicice (Federal University of Tocantins) and two anonymous referees for comments and suggestions that improved the manuscript. This project is part of the thematic project "Fauna e Flora de Remanescentes Florestais do Noroeste Paulista" funded by the São Paulo Research Foundation, FAPESP (process \#2008/03583-9). Diogo B. Provete and Robert L. Vadas Jr reviewed the English language. FBT received a doctoral fellowship from São Paulo Research Foundation - FAPESP (2008/03583-9) and LC receives a research productivity grant from the Brazilian National Council for Scientific and Technological Development - CNPq (306758/2010-5).

\section{Literature Cited}

Ahmadi-Nedushan, B., A. St-Hilaire, M. Bérubé, E. Robichaud, N. Thiémonge \& B. Bobée. 2006. A review of statistical methods for the evaluation of aquatic habitat suitability for instream flow assessment. River Research and Applications, 22: 503-523.

Angermeier, P. L. \& J. R. Karr. 1983. Fish communities along environmental gradients in a system of tropical streams. Environmental Biology of Fishes, 9: 117-135.

Araujo, R. B. \& V. Garutti. 2003. Ecology of a stream from upper Paraná river basin inhabited by Aspidoras fuscoguttatus Nijssen \& Isbrücker, 1976 (Siluriformes, Callichthyidae). Brazilian Journal of Biology, 63: 363-372.

Barletta, M., A. J. Jaureguizar, C. Baigun, N. F. Fontoura, A. A. Agostinho, V. M. F. Almeida-Val, A. L. Val, R. A. Torres, L. F. Jimenes-Segura, T. Giarrizzo, N. N. Fabré, V. S. Batista, C. Lasso, D. C. Taphorn, M. F. Costa, P. T. Chaves, J. P. Vieira \& M. F. M. Corrêa. 2010. Fish and aquatic habitat conservation in South America: a continental overview with emphasis on Neotropical systems. Journal of Fish Biology, 76: 2118-2176.

Bovee, K. D. 1982. A guide to stream habitat analysis using the instream flow incremental methodology. U.S. Fish and Wildlife Service, Instream Flow Information Paper 12. FWS?OBS-82/ 26.

Bovee, K. D. 1986. Development and evaluation of habitat suitability criteria for use in the instream flow incremental methodology. U.S. Fish and Wildlife Service, Washington, D.C., Instream Flow Information Paper 21, Biological Report, 86(7).

Bürhnheim, C. M. 2002. Heterogeneidade de habitats: rasos x fundos em assembléias de peixes de igarapés de terra firme na Amazônia Central. Revista Brasileira de Zoologia, 19: 889-905.

Casatti, L. \& R. M. C. Castro. 1998. A fish community of the São Francisco river headwater riffles, southeastern Brazil. Ichthyological Exploration of Freshwaters, 9: 229-242.

Casatti, L. \& R. M. C. Castro. 2006. Testing the ecomorphological hypothesis in a headwater riffles fish assemblage of the rio São Francisco, southeastern Brazil. Neotropical Ichthyology, 4: 203214.

Casatti, L., F. Langeani \& R. M. C. Castro. 2001. Peixes de riacho do Parque Estadual Morro do Diabo, bacia do alto rio Paraná, SP. Biota Neotropica, 1: 1-15.
Casatti, L., F. C. Rocha \& D. C. Pereira. 2005. Habitat use by two species of Hypostomus (Pisces, Loricariidae) in southeastern brazilian streams. Biota Neotropica, 5: 157-165.

Casatti, L., F. Langeani, A. M. Silva \& R. M. C. Castro. 2006. Stream fish, water and habitat quality in a pasture dominated basin, southeastern Brazil. Brazilian Journal of Biology, 66: 681-696.

Casatti, L., C. P. Ferreira \& F. R. Carvalho. 2009a. Grass-dominated stream sites exhibit low fish species diversity and dominance by guppies: an assessment of two tropical pasture river basins. Hydrobiologia, 623: 173-189.

Casatti, L., J. L. Veronezi-Júnior \& C. P. Ferreira. 2009b. Dieta do cascudo Aspidoras fuscoguttatus (Ostariophysi, Callichthyidae) em riachos com diferentes características limnológicas e estruturais. Biota Neotropica, 9: 1-9.

Castro, R. M. C., L. Casatti, H. F. Santos, K. M. Ferreira, A. C. Ribeiro, R. C. Benine, G. Z. P. Dardis, A. L. A. Melo, R. Stopiglia, T. X. Abreu, F. A. Bockmann, M. Carvalho, F. Z. Gibran, F. C. T. Lima. 2003. Estrutura e composição da ictiofauna de riachos do Rio Paranapanema, sudeste do Brasil. Biota Neotropica, 3: 1-31.

Ceneviva-Bastos, M., L. Casatti \& D. C. Rossa-Feres. 2010. Meso and microhabitat analysis and feeding habits of small nektonic characins (Teleostei: Characiformes) in Neotropical streams. Zoologia, 27: 191-200.

Clarke, K. R. \& R. M. Warwick. 2001. Change in marine communities: an approach to statistical analysis and interpretation. Plymouth Marine Laboratory, Plymouth, UK.

Ferreira, C. P. \& L. Casatti. 2006. Influência da estrutura do hábitat sobre a ictiofauna de um riacho em uma micro-bacia de pastagem, São Paulo, Brasil. Revista Brasileira de Zoologia, 23: 642-651.

Freeman, M. C., Z. H. Bowen \& J. H. Crance. 1997. Transferability of habitat suitability criteria for fishes in warmwater streams. North American Journal of Fisheries Management, 17: 20-31.

Gatz, A. J. Jr. 1979. Ecological morphology of freshwater stream fishes. Tulane Studies in Zoology and Botany, 21: 91-124.

Grinnell, J. 1917. The niche-relationship of the California thrasher. Auk, 34: 427-33.

Groshens, T. P. \& D. J. Orth. 1993. An assessment of the transferability of habitat suitability criteria for smallmouth bass. Virginia Water Resources Research Center Bulletin 180.

Hutchinson, M. F. 1957. Concluding remarks. Cold Spring Harbour Symposium on Quantitative Biology, 22: 415-427.

IPT (Instituto de Pesquisas Tecnológicas do Estado de São Paulo). 1999. Diagnóstico da situação atual dos Recursos Hídricos e estabelecimento de diretrizes técnicas para a elaboração do Plano da Bacia Hidrográfica do Turvo/Grande. Relatório $n^{\circ} 40.515$. Secretaria de Recursos Hídricos, Saneamento e Obras, São Paulo.

Jackson, D. A., P. R. Peres-Neto \& J. D. Olden. 2001. What controls who is where in freshwater fish communities - the roles of biotic, abiotic and spatial factors. Canadian Journal of Fisheries and Aquatic Sciences, 58: 157-170.

Lamouroux, N., H. Capra, M. Pouilly \& Y. Souchon. 1999. Fish habitat preferences in large streams of southern France. Freshwater Biology, 42: 673-687.

Leal, C. G., N. T. Junqueira \& P. S. Pompeu. 2011. Morphology and habitat use by fishes of the Rio das Velhas basin in southeastern Brazil. Environmental Biology of Fishes, 90: 143157.

Oliveira, E. F., E. Goulart, L. Breda, C. V. Minte-Vera, L. R. S. Paiva \& M. R. Vismara. 2010. Ecomorphological patterns of the fish assemblage in a tropical floodplain: effects of trophic, spatial and phylogenetic structures. Neotropical Ichthyology, 8: 569-586. 
Power, M. E. 1984. Depth distribution of armored catfish: predatorinduced resource avoidance? Ecology, 65: 523-528.

Rocha, F. C., L. Casatti \& D. C. Pereira. 2009. Structure and feeding of a stream fish assemblage in Southeastern Brazil: evidence of low seasonal influences. Acta Limnologica Brasiliense, 21: 123-134.

Schwartz, J. S. \& E. E. Herricks. 2008. Fish use of ecohydraulicbased mesohabitat units in a low-gradient Illinois stream: implications for stream restoration. Aquatic Conservation: Marine and Freshwater Ecosystems, 18: 852-866.

Silva, A. M., M. A. Nalon, F. J. A. N. Kronka, C. A. Álvares, P. B. Camargo \& L. A. Martinelli. 2007. Historical land-cover/use in different slope and riparian buffer zones in watershed of the State of São Paulo, Brazil. Scientia Agricola, 64: 325-335.

Strakosh, T. R., R. M. Neumann, R. A. Jacobson. 2003. Development and assessment of habitat suitability criteria for adult brown trout in southern New England rivers. Ecology of Freshwater Fish, 12: 265-274.

Teresa, F. B. \& L. Casatti. 2010. Importância da vegetação ripária em região intensamente desmatada no sudeste do Brasil: um estudo com peixes de riacho. Pan-American Journal of Aquatic Sciences, 5: 444-453.
Thomas, J. A. \& K. D. Bovee. 1993. Application and testing of a procedure to evaluate transferability of habitat suitability criteria. Regulated Rivers: Research and Management, 8: $285-$ 294.

Uieda, V.S., P. Buzzato \& R. M. Kikuchi. 1997. Partilha de recursos alimentares em peixes em um riacho de serra no sudeste do Brasil. Anais da Academia Brasileira de Ciências, 69: 243-252.

Vadas, R. L. Jr. \& D. J. Orth. 2001. Formulation of habitat suitability models for stream fish guilds: do the standard methods work? Transactions of the American Fisheries Society, 130: 217-235.

Watson, D. J. \& E. K. Balon. 1984. Ecomorphological analysis of fish taxocenes in rainforest streams of northern Borneo. Journal of Fish Biology, 25: 371-384.

Wright, J. P. \& A. S. Flecker. 2004. Deforesting the riverscape: the effects of wood on fish diversity in a Venezuelan piedmont stream. Biological Conservation, 120: 439-447.

Submitted September 16, 2012 Accepted March 23, 2013 by Fernando Pelicice

Published June 28, 2013 